\title{
Phytoliths of six woody species important in the Carpathians: characteristic phytoliths in Norway spruce needles
}

\author{
Zsuzsa Lisztes-Szabó ${ }^{1}\left[\right.$ D Mihály Braun ${ }^{1} \cdot$ Attila Csík $^{2} \cdot$ Ákos Petö $^{3}$
}

Received: 12 January 2018 / Accepted: 21 February 2019 / Published online: 14 March 2019

(c) The Author(s) 2019

\begin{abstract}
Phytoliths—also known as plant opals—are preserved in soils and sediments and have taxonomical relevance, therefore phytoliths can be fingerprints of the vegetation of the period from which they originated. Comparative phytolith studies are essential for finding phytolith morphotypes with taxonomic relevance. These are used to build reference collections for future palaeoecological and archaeobotanical studies. Biogenic silica extracted from the leaves of six woody species commonly occurring in temperate climate plant communities was examined using light and scanning electron microscope methods (Deciduous broad-leaved species: Corylus avellana, Fagus sylvatica, Quercus robur. Coniferous species: Abies alba, Picea abies, Pinus sylvestris). The element content of phytoliths was analysed by SEM EDX and the phytolith taxonomic diagnostic potential of element content was tested by discriminant analysis. An inventory of phytolith types with their anatomical origin was provided and type-frequencies were assessed. Three species have been systematically screened here for the first time in detail (C. avellana, F. sylvatica, $Q$. robur). This is the first time that a characteristic cubical phytolith morphotype ("Picea-вLоску type") originating from transfusion tissue was described as a distinct layer encompassing the central cylinder of the needle. High concentrations of aluminium and magnesium in phytoliths are associated with two of three conifer species. A. alba and $P$. sylvestris could be differentiated statistically on the basis of elemental content. Our findings open up the possibility to identify these taxa based on their phytoliths and it is anticipated that this could be a useful tool for phytolith identification originating from soils and sediments as well. Moreover, Picea-BLOCKY type allows comparative, in situ studies (amongst others isotopic) to provide the possibility of finding further measurable proxies.
\end{abstract}

Keywords Biogenic silica $\cdot$ Conifers $\cdot$ Elemental content $\cdot$ Picea abies $\cdot$ Phytolith $\cdot$ SEM EDX

\section{Introduction}

In the last two decades, an assortment of techniques for measuring ecosystem responses to environmental changes has expanded, revealing novel approaches to studies of past

Communicated by K. Neumann.

Zsuzsa Lisztes-Szabó

lisztes-szabo.zsuzsanna@atomki.mta.hu

1 Isotope Climatology and Environmental Research Centre, Institute for Nuclear Research, Hungarian Academy of Sciences, Bem tér 18/C, Debrecen 4026, Hungary

2 Laboratory of Electron Spectroscopy and Materials Science, Institute for Nuclear Research, Hungarian Academy of Sciences, Bem tér 18/C, Debrecen 4026, Hungary

3 Institute of Nature Conservation and Landscape Management, Szent István University, Páter Károly u. 1, Gödöllő 2100, Hungary environmental conditions. Multi-proxy studies, including phytolith analysis, gain a wider and wider understanding in palaeoenvironmental reconstructions using several physical and biotic proxies (Smol 2002; Birks and Birks 2006). In past years, the number of phytolith studies has grown exponentially (Hart 2016) and knowledge of silicon uptake and development of phytoliths is increasing (Hodson et al. 1985; Epstein 1999; Soukup et al. 2014, 2017), but is incomplete. Monosilicic acid is taken up by plant roots from porewater of the soil and precipitates in cell walls, cell lumens or intercellular spaces in the form of $\mathrm{SiO}_{2} \mathrm{n}\left(\mathrm{H}_{2} \mathrm{O}\right)$ in several organs of the plant. These micrometric amorphous opal particles occur in several plant species of about 50 families of higher plants (Piperno 2006) and are called phytoliths. As phytoliths are preserved in soils and sediments after the decomposition of the plants, and in a manner that has taxonomical relevance, phytoliths can be fingerprints of the vegetation of the period from which they originate (Piperno 2006). 
Phytolith analysis of soils and sediments potentially gives more particular and local data of vegetation change than pollen analysis (Rovner 1988; Rosen 1994; Lentfer and Boyd 1998), and is a useful source of evidence when other micro- or macrobotanical remains are absent (Neumann et al. 2017). Palaeoenvironmental reconstruction based on only one proxy may not lead to reliable results in every case, but phytolith analysis may be useful to complement pollen analyses, macrobotanical and other studies (An et al. 2015; Chen et al. 2015; Solis-Castillo et al. 2015; Sakai et al. 2016; Neumann et al. 2017; Woodburn et al. 2017).

Environmental and vegetation reconstruction phytolithstudies concentrate mainly on the Palaeotropis and Neotropis, for America and Japan (Mulholland et al. 1992; Bozarth 1993; several relevant sources have been summarized in Carnelli et al. 2004 and Hart 2016). Phytolith assemblage-based reconstruction studies are not available so far for the Carpathian Mountains region. Only a few phytolith studies of mountain species are available in Europe: for the Caucasus (Kiseleva 1992; Blinnikov 1994), for the Alps (Carnelli et al. 2001, 2004) and for the lower-elevation mountain ecosystem in eastern France (Bremond et al. 2004).

Since 2000, more and more new technological advances have become available to refine and broaden the application of phytolith analysis, and Hart (2016) reinforces this with the term "Period of Expanding Applications". One of the measurable characteristics of phytoliths, which may be important to identify a plant taxon, is the chemical element content. A few studies suggested that the elemental composition of phytoliths correlates with taxonomic relevance, and it may be a useful tool for identifying the plant taxon that was present in the period being investigated; also this may give us information about the type of the soil in which the plant grew (Hart 2001; Buján 2013). It seems that the elemental composition of phytoliths may be helpful to identify a widely-defined plant taxon, especially in the case where the identification of a phytolith morphotype is ambiguous or not typical (cf. multiplicity and redundancy; Rovner 1971). Besides metabolic carbon and nitrogen, the most remarkable element in phytoliths is aluminium. The plant opal material of conifers contains a high amount of aluminium, even more than deciduous species (Piperno 1988; Hodson and Sangster 1998). Based on Bartoli and Wilding (1980), phytoliths with higher aluminium content are more resistant to weathering agents in the soil-sediment system. However, other taphonomical studies showed that impure phytoliths were more susceptible to weathering, because of the impurities causing irregularities in the continuum of opal silica matrix (Osterreith et al. 2009).

A reference phytolith database for the Carpathian Mountains and the Carpathian Basin region was designed and built in order to establish a plant-based reference key for palaeoenvironmental studies, and here we report on a part of it. In this paper, we investigate a characteristic occurrence of phytoliths in Picea abies [L.] H.Karst (Norway spruce) needles. Leaf phytolith assemblages and biogenic silica content of $P$. abies needles and leaves of another five tree species are described and compared (deciduous: Corylus avellana L., Fagus sylvatica L., Quercus robur L., coniferous: Abies alba Mill., Pinus sylvestris L.). The phytolith assemblages of the species studied here are important in a palaeoecological view of the early Holocene for the Carpathian Basin and the Carpathian Mountains (Soó 1930; Juhász 2005; Magyari et al. 2014; Buró et al. 2016; Molnár and Végvári 2017; Hubay et al. 2018; Tapody et al. 2018 and others). At the same time, the elemental compositions of leaf phytoliths for the three coniferous and three deciduous tree species were measured from ash by energy-dispersive X-ray spectroscopy (EDX) to look for any correlation between the species and elemental content that could have diagnostic potential.

\section{Materials and methods}

Apart from Picea abies, two coniferous and three deciduous woody species were chosen that are relevant for palaeo- and recent vegetation and at the same time have higher biogenic silica content, as well as identifiable leaf phytoliths (Table 1).

Material was collected at the end of the vegetation growing period from the Botanical Garden of Debrecen University (Hungary) in the beginning of November 2016. Thus, leaves contained the total annual silicon amount that is characteristic for the species. The soil type can affect mineral uptake of leaves (Hodson and Sangster 1998), but the soil conditions were regarded as essentially the same in this case, thus differences in element uptake between the different species could be assessed. We attempted to collect leaves from more than one tree. For Corylus avellana, Fagus sylvatica and Quercus robur, composite leaf samples from a few branches of 5,2 and 3 individuals, respectively, were collected randomly. For Abies alba, Picea abies and Pinus sylvestris, composite samples of evergreen needles were collected from a few branches of 3,5 and 3 individuals, respectively. We attempted to sample different aged needles, because the accumulation of elements varies in needles of different age (Hodson and Sangster 1998).

Phytolith extraction from the leaves was accomplished in three repetitions through the dry-ashing technique (Albert and Weiner 2001; Mercader et al. 2010). Samples were washed intensively in distilled water using sonication (ultrasonic cleaning bath) and then were dried at $105{ }^{\circ} \mathrm{C}$ overnight and weighed. After this samples were combusted in a furnace at $500{ }^{\circ} \mathrm{C}$ for $8 \mathrm{~h}$, then $3 \mathrm{~mol} \mathrm{l}^{-1} \mathrm{HCl}$ and $3 \mathrm{~mol} \mathrm{l}^{-1} \mathrm{HNO}_{3}$ solution was added and the ash was treated for $30 \mathrm{~min}$ at $100{ }^{\circ} \mathrm{C}$. The acid-insoluble fraction 
Table 1 The sampled deciduous and coniferous species with present and earlier published data of biogenic silica content $\%$ (bSi) of the leaves dry weight with standard deviation (s.d.)

\begin{tabular}{llllll}
\hline & Species & Family & bSi $\% \pm$ s.d. & Published bSi \% & Authors \\
\hline Deciduous & Corylus avellana L. & Betulaceae & $2.32 \pm 0.16$ & & \\
& Fagus sylvatica L. & Fagaceae & $2.06 \pm 0.12$ & 1.59 & 1 \\
& Quercus robur L. & Fagaceae & $3.04 \pm 0.07$ & 1.17 & 1 \\
Coniferous & Pbies alba Mill. & Pinaceae & $1.16 \pm 0.27$ & 0.06 & 2 \\
& Picea abies (L.) Karst & Pinaceae & $1.97 \pm 0.09$ & 0.85 & 2 \\
& & & & 0.97 & 1 \\
& & & & $0.3-3.7$ & 3 \\
& & & & $2.35-2.78$ & 4 \\
& Pinus sylvestris L. & Pinaceae & $0.78 \pm 0.19$ & $0.05-0.1$ & 3 \\
\hline
\end{tabular}

1. Cornelis et al. (2010); 2. Carnelli et al. (2001); 3. Bartoli and Souchier (1978); 4. Hodson et al. (1997). 5. Klein and Geis (1978) was centrifuged three times (3,000 rpm for $2 \mathrm{~min})$ and the supernatant was discarded and re-suspended. Then, hydrogen peroxide $\left(\mathrm{H}_{2} \mathrm{O}_{2}\right)$ was added and samples were dried at $105{ }^{\circ} \mathrm{C}$ and were weighed. The resulting mass was the biogenic silica content that is usually given as a percentage of the dry weight of the sample. The ashes were mixed thoroughly and phytoliths were mounted on microscope slides in immersion oil and observed under an Olympus BH-2 polarized light microscope at a magnification of $1,000 \times$. Optically isotropic phytoliths were checked using cross-polarised illumination. In addition, the phytolith samples were stored in Eppendorf tubes in the Phytolith Collection of Isotope Climatology and Environmental Research Centre (ICER) with a laboratory code of 115-1073.1. A total of 500 phytoliths in all samples of one species were counted in adjacent but not overlapping lines across the cover slip.

The typological and taxonomical types of approach for phytolith analysis are combined in this study, since the morphotypes are described by using the International Code for Phytolith Nomenclature (ICPN) 2.0 (ICPT 2019), however their anatomical origin is emphasized and used as the most important attribute of these phytoliths. Thus, whenever it was possible, the phytolith morphotypes were described based on the anatomical origin of the given morphotype, because the knowledge of the anatomical structure may increase the usefulness of the phytoliths in palaeoecological studies. Because of this, in Table 2 collective nouns for the morphotypes according to their anatomical origin are listed. Morever, phytolith names created by Carnelli et al. (2004) are also given (in italics below), because we considered the phytolith assemblage data of the Alpine species as a possible baseline dataset for comparison. The study of Carnelli et al. (2004) was published ahead of ICPN 1.0, therefore phytoliths are not denominated according to the rules of the ICPN 1.0 nomenclature. Phytolith morphotype names are written in small capitals according to ICPN 2.0 (ICPT 2019).
Phytolith morphotypes were measured and documented by microphotographs (ScopePhoto, Version 3.1.615). Large fragments of silicified tissues were considered as representative features, but intercellular deposits or other small and undefined fragments were not included in the count.

Ash from the leaves was spread with a paint brush onto double-sided tape mounted on an aluminium stub and then the ash sample was coated with gold (BIO-RAD E5000C Sputter Coater). The well-characterized phytolith forms were randomly measured by elemental analysis, without considering their anatomical origin. Consequently, the proportion of the measured phytolith morphotypes was considered to be equivalent to the proportion of the phytolith morphotypes in the sample. More than 10 phytoliths were measured per species (13 C. avellana, $20 \mathrm{~F}$. sylvatica, 13 Q. robur, 12 A. alba, 17 P. abies and 12 P. sylvestris phytoliths were examined). Elemental analysis of phytoliths was conducted with a Hitachi S4300-CFE scanning electron microscope using Energy Dispersive X-ray Fluorescence, operating at $15 \mathrm{kV}$ with a detection threshold of 0.1 atom $\%$. The elements detected were the following: $\mathrm{Si}, \mathrm{O}, \mathrm{C}, \mathrm{Mg}, \mathrm{Al}, \mathrm{P}, \mathrm{S}$, $\mathrm{K}, \mathrm{Ca}, \mathrm{Mn}, \mathrm{Na}, \mathrm{Ti}, \mathrm{Ba}, \mathrm{Fe}$. The anatomical position of the silicon accumulation was examined by X-ray element mapping. Phytoliths were identified in situ in the tissues on the longitudinal and cross sections of leaves cut by blade under a Zeiss Stereo Discovery.v20 microscope. Microphotos of phytoliths were also taken in situ.

The element contents of the phytoliths revealed from the six species were compared by ANOVA. Moreover, these six groups of phytolith samples, a priori ordered according to species, were classified by linear discriminant analysis (LDA) using SPSS/PC+ (Norušis 1990). The SEM-EDX data are expressed as proportions of a fixed total, this approach can cause a problem with compositional data (Swan and Sandilands 1995). Following the suggestions of Aitchison (1986) discriminant analysis was run on the logratio transformed data. Concentrations of $\mathrm{Ba}, \mathrm{Fe}, \mathrm{Na}$ and 
Table 2 Morphotype percentages in relation to all counted phytoliths with longest sizes of phytoliths and ubiquity: number of species where the morphotype was present

\begin{tabular}{|c|c|c|c|c|c|c|c|c|c|}
\hline Phytolith morphotype & Carnelli et al. (2004) & $\begin{array}{l}\text { Size } \\
(\mu \mathrm{m})\end{array}$ & Corav & Fagsyl & Querob & Abal & Picab & Pinsyl & $\begin{array}{l}\text { Ubiquity/ } \\
6 \text { species }\end{array}$ \\
\hline Jigsaw epidermal cells & Jigsaw epidermal cells & $18-41$ & 22.6 & 52.6 & & & & & 2 \\
\hline Isodiametric epidermal cells & & $10-45$ & & & 40.8 & & & & 1 \\
\hline Stoma & Stoma & $23-50$ & & & 0.9 & 6.8 & 0.9 & 3.0 & 4 \\
\hline ACICULAR; ACUTE BULBOSUS & Trichoma & $57-73$ & 3.3 & & 1.3 & & & & 2 \\
\hline Idioblast & & $12-33$ & 9.0 & & & & & & 1 \\
\hline ELONGATE SINUATE & $\begin{array}{l}\text { Undulated hypodermal } \\
\text { cells }\end{array}$ & $33-60$ & & & & & 39.4 & & 1 \\
\hline Mesophyll cells & Mesophyll cells & $4-8$ & 28.6 & 31.5 & 2.7 & & & & 3 \\
\hline $\begin{array}{l}\text { TRACHEARY ANNULATE/HELICAL; } \\
\text { TRACHEARY BORDERED }\end{array}$ & Trachea/tracheids & $35-98$ & 25.2 & 15.7 & 11.7 & & & 15.1 & 6 \\
\hline $\begin{array}{l}\text { POLYHEDRAL of conifers; } \\
\text { BLOCKY of conifers }\end{array}$ & $\begin{array}{l}\text { Polyhedron of conifers / } \\
\text { blocky }\end{array}$ & $19-66$ & & & & 46.6 & 56.3 & 32.3 & 3 \\
\hline $\begin{array}{l}\text { ELLIPSOIDAL MACULOSE; } \\
\text { BULBOUS RECTANGULAR } \\
\text { MACULOSE }\end{array}$ & Polyhedral cell / blocky & $19-51$ & 9.8 & & 9.2 & & & & 5 \\
\hline ELONGATED PITTED & & $83-87$ & & & 24.5 & & & & 1 \\
\hline ELONGATED ENTIRE & & $38-66$ & & & & 7.8 & 3.1 & & 2 \\
\hline SPHEROID PSILATE & Spherical & $4-10$ & & & & 29.0 & & 37.3 & 2 \\
\hline Silica skeleton & Silica skeleton & $11-84$ & & & & 9.8 & & 4.0 & 2 \\
\hline Sclereid & & $32-61$ & & & 7.8 & & & & 1 \\
\hline SPHEROID & Spherical & $6-8$ & 1.1 & & & & & & 1 \\
\hline Number counted (100\%) & & 500 & 530 & & 509 & 500 & 532 & 500 & \\
\hline
\end{tabular}

Synonyms used according to Carnelli et al. (2004). Corav: Corylus avellana, Fagsyl: Fagus sylvatica, Querob: Quercus robur, Abal: Abies alba, Picab: Picea abies, Pinsyl: Pinus sylvestris

Ti were under detection limit in many cases, therefore they were excluded from the analysis.

\section{Results}

\section{Biogenic silica content}

The highest percentage of silica was found in $Q$. robur leaves (mean value with standard deviation; $3.04 \pm 0.07 \%$ ), and it was also relatively high in $C$. avellana and $F$. sylvatica leaves $(2.32 \pm 0.16 \%$ and $2.06 \pm 0.12 \%)$ (Table 1). Among the three coniferous species, the highest percentage of silica was found from the leaves of $P$. abies $(1.97 \pm 0.09 \%)$, whereas the leaves of $A$. alba and P. sylvestris contained $1.16 \pm 0.27 \%$ and $0.78 \pm 0.19 \%$, respectively.

\section{Phytolith morphotype descriptions}

The distribution of a total of 16 phytolith morphotypes is described below and summarised in Table 2 . The phytolith morphotypes were divided into two groups: epidermal tissue fragments and non-epidermal phytoliths.

\section{Epidermal tissue fragments}

Ash from the leaves of the sampled species was rich in silicified epidermal fragments with characteristics that typified the species, particularly if the tissue fragments usually contain stomata, idioblasts and hairs. Epidermal fragments are more frequently observed in identifiable phytolith assemblages of the sampled broad-leaved specimens than in assemblages of coniferous specimens. Two types of silicified epidermal tissue were found, jigsaw epidermal cells and the tissue of isodiametric epidermal cells (Fig. 1, 1-6). Two of the three deciduous species shown in this study contained strongly silicified jigsaw epidermal cells ( $C$. avellana, $F$. sylvatica) from the adaxial surface of the leaf (Fig. 1, 4-5). Isodiametric epidermal cells were the feature of $Q$. robur from both of adaxial and abaxial epidermis surfaces (Fig. 1, 1 and 6 ).

At the same time, epidermal fragments are often identifiable based on the stomata, hairs or idioblasts attached to them. Stomata occurred in samples of every species at least embedded in the epidermal tissue (Fig. 1, 7-13). The ash of $C$. avellana and $F$. sylvatica leaves included stomata mainly in the epidermal fragments, but samples of conifers and $Q$. 

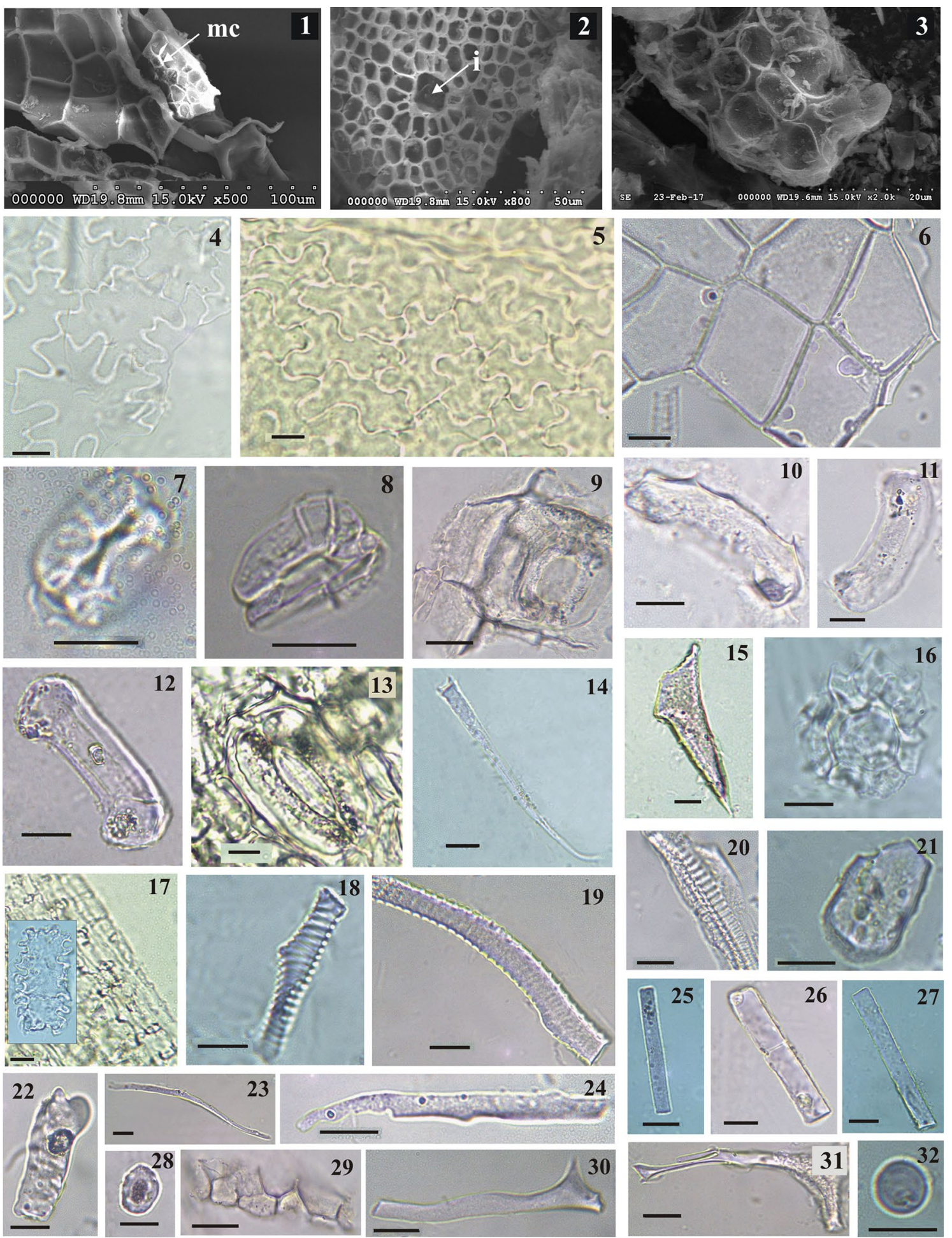

Fig. 1 1-3: SEM pictures of 1 silicified epidermal tissue of Quercus robur leaf, mc: mesophyll cells, 2 silicified mesophyll cells of $Q$. robur leaf, i: cavity of an idioblast, $\mathbf{3}$ silicified mesophyll cells of Fagus sylvatica. 4-32: Light microphotographs of 4 Corylus avellana jigsaw epidermal cells, $\mathbf{5} F$. sylvatica jigsaw epidermal cells, $\mathbf{6} Q$. robur isodiametric epidermal cells, 7-8 $Q$. robur stoma, 9-12 Abies alba stoma, 13 Picea abies stoma, 14 C. avellana ACICULAR, $15 Q$. robur ACUTE BULBosus, 16 C. avellana idioblast, 17 P. abies tissue of ELONGATE SINUATE cells with an embedded photo of an ELONGATED SINUATE cell, 18-20 C. avellana TRACHEARY ANNULATE/HELICAL, 21 . avellana ELLIPSOIDAL, 22 Q. robur BULBOUS RECTANGULAR, 23-24 $Q$. robur ElOngate, 25-27 A. alba ElONGATE EnTIRe, 28 Pinus sylvetris SPHeroid PSILATE, 29 P. sylvestris silica skeleton, 30-31 $Q$. robur BRACHIATES, 32 C. avellana SPHEROID. Scale bars: $10 \mu \mathrm{m}$ 
robur contained abundant discrete guard cells. The ashes from the leaves of A. alba and P. sylvestris were richer in stomata than samples of $P$. abies. ACICULAR and ACUTE BULBOSUS phytoliths were observed in C. avellana and $Q$. robur leaves ash (Fig. 1, 14-15), by contrast the hairs in the $F$. sylvatica leaf edge proved to be less persistent and were broken in the ash. These types of silicified trichomes were published earlier as trichomas (Carnelli et al. 2004). Moreover, idioblast cell remains of calcium-oxalate druses and hair bases in the epidermis of $C$. avellana were frequently observed in isodiametric epidermal tissue fragments. Sub-epidermal silicified cell complexes were only found in P. abies.

\section{Non-epidermal phytoliths}

Silicified mesophyll cells connected to epidermis were found in leaves of deciduous trees (Fig. 1, 2-3 and 16). Fragments of jigsaw epidermal cells with attached silicified mesophyll tissue were also found, but the silicified cells in the deciduous species did not form a peculiar discrete layer. Silicified tissue occurred under the epidermis also in the spruce needles as a hypodermis (Fig. 1, 17). These are ELONGATED SINUATE cells, and Carnelli et al. (2004) named them undulated hypodermal cells.

The leaves of the studied species were rich in TRACHEARY, with varied morphology. These forms are mentioned with synonyms, as tracheids or vessels in Carnelli et al. (2004). Moreover, different studies such as Carnelli et al. (2004) also used the following morphotype names: polyhedron of conifers, polyhedral cell or blocky for these silicified cells, but several phytoliths of those referred to originated unambiguously from the water conducting system, because they had pitted ornament on the surfaces (Plate VI, 1-2 in Carnelli et al. 2004, p 57). However, according to ICPN 2.0, in that case, if cell walls display rings, spiral, pitted or bordered ornaments, these elements are from the water conducting system and these belong to the TRACHEARY morphotype. Consequently, we classified a phytolith as belonging to the TRACHEARY morphotype category, if there was no doubt that the physiological role of it was the water transport system (in the cases of deciduous species and P. sylvestris, Table 2). In some measure there is taxonomical relevance of these morphotypes. Deciduous trees have vessels with different spiral and circular walls, these are TRACHEARY ANNULATE/HELICAL morphotypes (Fig. 1, 18-20). These spiral and circular cell wall ornaments are often missing in conifers (but not always, Klein and Geis 1978) and these more or less distinguish the deciduous species from conifers. Ash of the $P$. sylvestris needles contained TRACHEARY BORDERED phytoliths (Table 2).

The most characteristic phytoliths of the studied needles-based on their shape and material texture-originated from the transfusion tissue. These phytoliths represent the highest percent of the phytoliths in the needles of our studied conifer species. The $46.6 \%$ of classifiable phytoliths belonged to this tissue in A. alba needles and this value was $56.3 \%$ in $P$. abies needles and $32.3 \%$ in $P$. sylvestris needles (Table 2). According to Carnelli et al. (2004) and An (2016) the phytolith morphotype that originates from the transfusion tissue (transfusion tracheids or transfusion parenchymatic cells) is BLOCKY and these are often pitted (cf. blocky scrobiculate; An 2016). Similarly to the TRACHEARY, there are several synonyms of the BLOCKY morphotype mentioned in the literature, such as polyhedron of conifers, polyhedral cells and also blockies (Carnelli et al. 2004; An 2016; Table 2). An (2016) described this phytolith type as blocky with smooth edges having a psilate to irregular surface, sometimes with wrinkles or pits. Carnelli et al. (2004) called it polyhedron of conifers, and stated that blocky polyhedron transfusion cells are often pitted.

In our samples, these abundant phytoliths originating from the transfusion tissue were smooth, granulated, or pitted in needles of every studied conifer species. However, we found that the form of $80-90 \%$ of these phytoliths was typical for the species studied (Fig. 2). About $10-20 \%$ of these phytoliths originating from the transfusion tissue were irregular in the three conifer needles. The most typical phytoliths of the sampled needles are described as follows. A. alba needles produced POLYHEDRAL phytoliths with one of the endpoints more or less tapering, sometimes occurring in clusters (Fig. 2a). The shape of these resembles a lance-head, several times longer than wide, broadest above the base and narrowed to the apex, the margins are velloate, with a surface
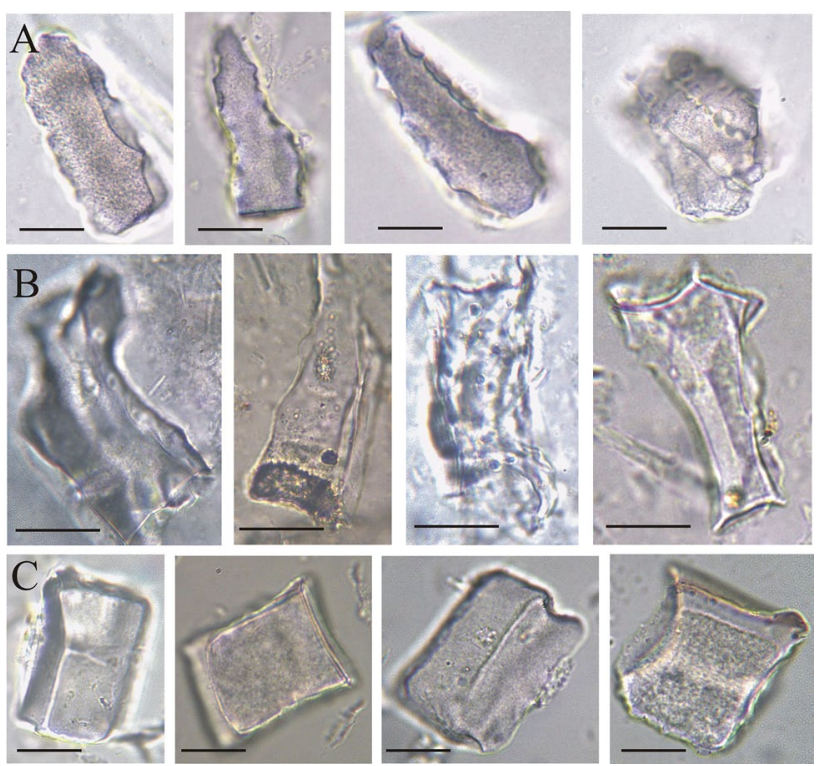

Fig. 2 Light microphotographs of characteristic phytoliths from transfusion tissue of needles of studied conifers. POLYHEDRAL a Abies alba, b Pinus sylvestris, BLOCKY, c Picea abies. Scale bars: $10 \mu \mathrm{m}$ 
marked with relatively big and shallow depressions. $P$. sylvestris had more irregular-shaped POLYHEDRAL morphotypes with one or more concave sides (Fig. 2b). P. abies had almost cubic or parallelepipedal-shaped (a four-faced geometrical figure in which every face is parallel to the opposite side) phytoliths with more or less equal sides (with length/width $\leq 2$, Fig. 2c). These cubic or almost cubic BLOCKY phytoliths can be observed in needles of Picea wilsonii and also of P. asperata as An (2016) mentioned, and we confirmed the last author's description of this form, that was the following: "This type is characterized by smooth surfaces, sharp sections or sides, and is concave on one or both sides, with sharp edges, clear ridges and distinct corners, sometimes in clusters. The length of a side is $30-40 \mu \mathrm{m}$ " (Fig. 2c).

A few, less characteristic silicified cells in leaves of deciduous $C$. avellana and $Q$. robur were found with unknown origin (Fig. 1, 21-22). Leaves of C. avellana had ELLIPSOIDAL MACUlose while $Q$. robur had BULBOUS/RECTANGULAR MACULOSE phytoliths with about $9 \%$ of the total phytolith number (Table 2). Carnelli et al. (2004) mentioned presumably similar, irregular phytoliths of deciduous species examined by them (Arctostaphylos, Calluna, Loiseleuria, Rhododendron, Vaccinium and Alnus spp.) as blocky and "polyhedral cells". Other phytolith types created by the xylem were the ELONGATED ENTIRE morphotype found in P. abies and A. alba needle samples (Fig. 1, 25-27). These phytoliths were not frequent and their origin may be the xylem. The origin of the ELONGATED forms with irregular edges in $Q$. robur leaves may also be the xylem, but these forms were not useful for species identification. The ELONGATED phytolith morphotype in samples of $Q$. robur was probably derived from the xylem and represented a transitional form between the sclereid and tracheid cells (Fig. 1, 23-24). In addition, some SPHEROID PSILATE phytoliths were in the ash of C. avellana leaves (Fig. 1, 32). SPHEROIDs are often found in phytolith assemblages of trees (for instance in Juniperus nana leaves; Carnelli et al. 2004). BRACHIATES were detected occasionally in $Q$. robur leaves, which were thin phytoliths with thick walls (Fig. 1, 30-31).

Silicified tissues with an unknown anatomical origin were present in P. sylvestris and A. alba, as Carnelli et al. (2004) also observed in Pinus mugo and Picea abies leaves (Fig. 1, 29). Several sPHEROIDS were revealed with scrobiculate ornament or without any ornament from $P$. sylvestris and A. alba leaves that were similar to grass short cells and their origin was perhaps the endodermis (Fig. 1, 28). Rare phytolith types observed in our samples were not included in this study, particularly because they had no identification value.

\section{Anatomical position of conifer phytoliths with species-identification value}

Because the questionable phytoliths presumably originated from the central part of the needles (presumably from the endodermis, transfusion tissue or xylem), X-ray mapping was focusing on this area. The $\mathrm{X}$-ray mapping did not show any well-characterized opal particles in the cross sections (Fig. 3A-b, B-b) or longitudinal sections (Fig. 3A-c, B-c) of A. alba and P. sylvestris leaves. The silicon maps showed only a diffuse silicon distribution that did not imply any silicon accumulation. This suggests that the polyhedral phytoliths of A. alba and P. sylvestris needles originated from xylem or transfusion tissue, but were less abundant than the polyhedral phytoliths of $P$. abies needles. Specifically, in $P$. abies leaves a layer of accumulated silicon and phytoliths could be found adjacent to the inner side of the endodermis (Fig. 3C). On a few phytoliths a specific peak (in fact an edge-with a three dimensional aspect) can be seen in the cross section (Fig. 3C d, arrow). These edges show the joining area of the phytolith to the endodermis cells. In the apex of the needle, the phytolith layer almost surrounds the vascular system (Fig. 3C-c, C-f), when compared with the middle part of the needle (Fig. 3C-b, C-e). These characteristic phytoliths could be found by observation by stereomicroscopy (Fig. 3C).

\section{Elemental content of phytoliths}

The elements with concentrations above 0.2 atom \% included $\mathrm{Si}, \mathrm{O}, \mathrm{C}, \mathrm{Mg}, \mathrm{Al}, \mathrm{P}, \mathrm{S}, \mathrm{K}, \mathrm{Ca}$, Mn (Table 3). Elements detected below 0.2 atom $\%$ were $\mathrm{Na}, \mathrm{Ti}, \mathrm{Ba}, \mathrm{Fe}$. As the latter elements likely originated from contamination, they are not relevant to palaeoenvironmental studies due to their low abundance; we did not consider them within the framework of this study.

Some of the element contents were higher in the phytoliths of conifers (especially in A. alba) than in the nonconifer species phytoliths. A. alba and $P$. sylvestris have significantly more magnesium content in their leaf phytoliths than in those of $F$. sylvatica. Significantly more aluminium was also measured in A. alba (the mean atom \% 1.2; 95\% confidence intervals $0.8-1.7$ ) and P. sylvestris (mean atom $\% 0.3 ; 95 \%$ confidence intervals $0.9-1.7$ ) than in deciduous species phytoliths. Similar to magnesium, the aluminium content was not higher in P. abies needle phytoliths than in deciduous species phytoliths. The presence of aluminium in conifer phytoliths was an expected result. Atom percent values for leaf phytolith phosphorus, potassium and calcium content were higher in conifers (the highest value for phosphorus in A. alba $0.9 ; 95 \%$ confidence intervals $0.2-1.6$, for 

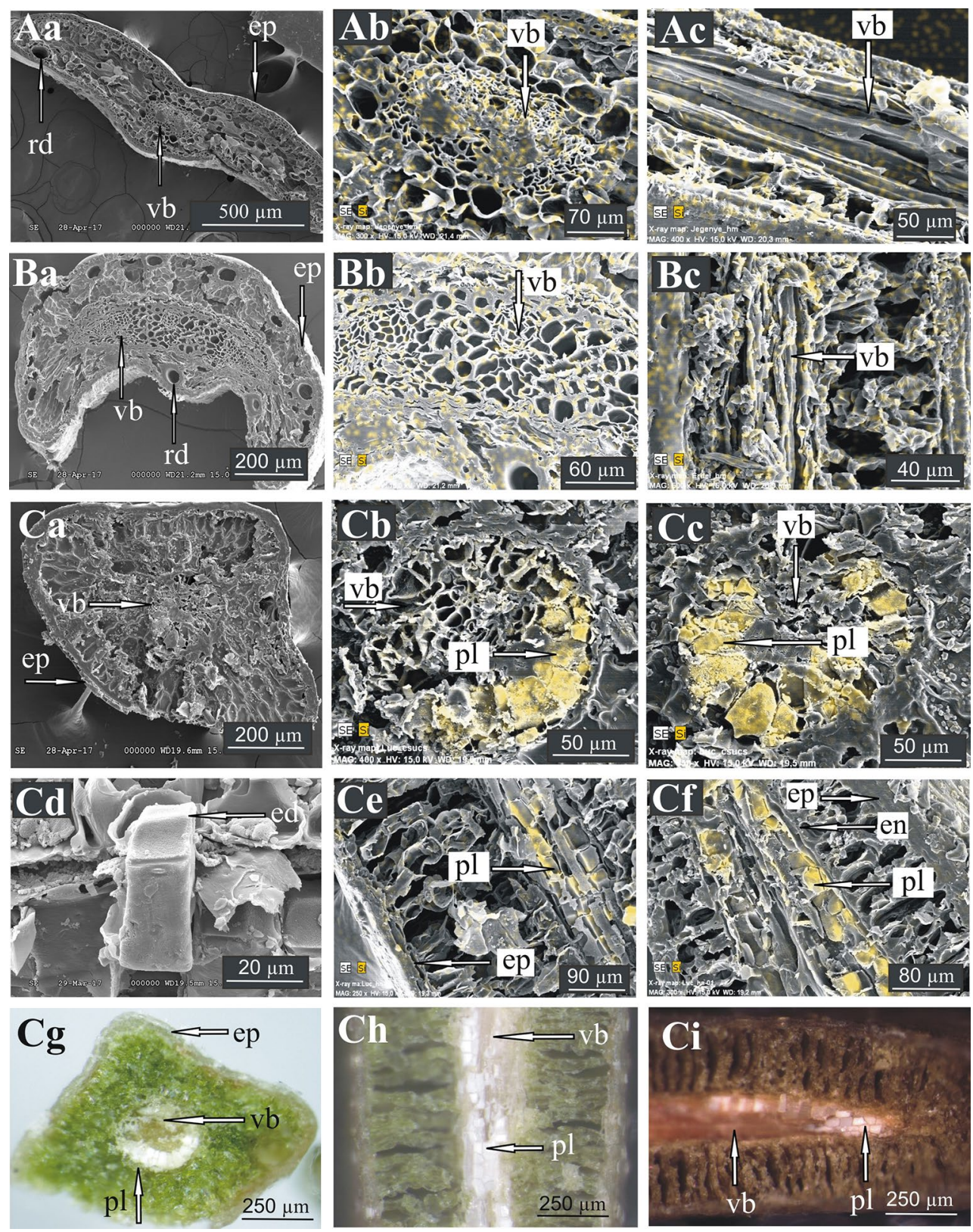

Fig. 3 SEM pictures, X-ray maps and stereomicroscopic pictures (SMP; g, h, i) of the sections of the needles. Si in yellow. A Abies alba (a) cross section (b) X-ray map of the central cylinder in the cross section (c) X-ray map of the longitudinal section. B Pinus sylvestris (a) cross section (b) X-ray map of the central cylinder in the cross section (c) X-ray map of the longitudinal section. C Picea abies (a) cross section (b) X-ray map of the central cylinder in the cross section in the middle of the needle (c) X-ray map of the central cylin-

potassium 1.0; 95\% confidence intervals $0.1-1.8$, for calcium 2.6; $95 \%$ confidence intervals 1.1-3.9), but without significant differences. der in the cross section in the apex of the needle (d) SEM picture of a "Picea-BLOCKY type" phytolith (e) X-ray map of the longitudinal section in the middle of the needle (f) X-ray map of the longitudinal section in the apex of the needle (g) cross section (h) longitudinal section in the middle of the needle (i) longitudinal section in the apex of the needle. $e p$ epidermis, $r d$ resin duct, $v b$ vascular bound, $p l$ phytolith layers, $e d$ joining edge of the endodermis cells, en endodermis

\section{Discriminant analysis (LDA)}

The suitability of using a discriminant approach to classify the phytoliths according to their elemental content was confirmed. Five significant $(\mathrm{p}<0.05)$ discriminant functions were obtained (Table 4). The first two discriminant functions 
Table 3 Means of element content (atom \%) with confidence intervals (95\%) of the species

\begin{tabular}{|c|c|c|c|c|c|c|c|c|c|c|}
\hline & $\mathrm{Si}$ & $\mathrm{O}$ & $\mathrm{C}$ & $\mathrm{Mg}$ & $\mathrm{Al}$ & $\mathrm{P}$ & S & $\mathrm{K}$ & $\mathrm{Ca}$ & Mn \\
\hline Quercus robur & $24.2( \pm 4.5)$ & $67.5( \pm 4.0)$ & $5.7( \pm 4.2)$ & $0.3^{\mathrm{ab}}( \pm 0.3)$ & $0.1^{\mathrm{a}}( \pm 0.1)$ & $<0.2$ & $<0.2$ & $0.4( \pm 0.28)$ & $1.0( \pm 0.98)$ & $<0.2$ \\
\hline Corylus avellana & $21.8( \pm 5.5)$ & $68.6( \pm 4.8)$ & $5.4( \pm 3.8)$ & $0.5^{\mathrm{ab}}( \pm 0.4)$ & $0.2^{\mathrm{a}}( \pm 0.2)$ & $<0.2$ & $<0.2$ & $0.3( \pm 0.2)$ & $1.7( \pm 1.5)$ & $<0.2$ \\
\hline Fagus sylvatica & $24.3( \pm 4.7)$ & $66.6( \pm 4.6)$ & $5.9( \pm 2.7)$ & $0.1^{\mathrm{a}}( \pm 0.1)$ & $0.2^{\mathrm{a}}( \pm 0.2)$ & $0.6( \pm 0.6)$ & $<0.2$ & $<0.2$ & $1.1( \pm 1.0)$ & $<0.2$ \\
\hline Abies alba & $19.6( \pm 5.1)$ & $66.0( \pm 4.2)$ & $4.7( \pm 3.7)$ & $0.9^{\mathrm{b}}( \pm 0.6)$ & $1.2^{\mathrm{b}}( \pm 0.7)$ & $0.9( \pm 1.0)$ & $<0.2$ & $1.0( \pm 0.8)$ & $2.6( \pm 2.0)$ & $<0.2$ \\
\hline Picea abies & $24.1( \pm 7.1)$ & $66.0( \pm 6.6)$ & $5.0( \pm 4.8)$ & $0.4^{\mathrm{ab}}( \pm 0.4)$ & $0.2^{\mathrm{a}}( \pm 0.2)$ & $0.5( \pm 0.5)$ & $<0.2$ & $0.9( \pm 0.8)$ & $2.1( \pm 1.9)$ & $<0.2$ \\
\hline Pinus sylvestris & $22.5( \pm 5.1)$ & $65.9( \pm 2.7)$ & $4.6( \pm 1.8)$ & $0.5^{\mathrm{b}}( \pm 0.4)$ & $0.3^{\mathrm{b}}( \pm 0.6)$ & $<0.2$ & $<0.2$ & $0.9( \pm 0.6)$ & $1.4( \pm 1.6)$ & $<0.2$ \\
\hline range & $19.6-24.3$ & $65.9-68.6$ & $4.6-5.9$ & $0.1-0.9$ & $0.1-1.2$ & $<0.2-0.9$ & $<0.2$ & $<0.2-1.0$ & $1.0-2.6$ & $<0.2$ \\
\hline
\end{tabular}

Means with different letters $(\mathrm{a}, \mathrm{b})$ are significantly different $(\mathrm{p}<0.05)$

Table 4 Pooled within-groups correlations between discriminating variables and standardized canonical discriminant functions with eigenvalues and cumulative $\%$ of variance

\begin{tabular}{|c|c|c|c|c|c|}
\hline \multirow[t]{2}{*}{ Elements } & \multicolumn{5}{|l|}{ Function } \\
\hline & 1 & 2 & 3 & 4 & 5 \\
\hline $\mathrm{Al}$ & $-0.775^{\mathrm{a}}$ & 0.109 & 0.250 & 0.082 & 0.015 \\
\hline K & 0.301 & $0.631^{\mathrm{a}}$ & 0.100 & 0.099 & 0.281 \\
\hline S & 0.079 & $0.521^{\mathrm{a}}$ & 0.494 & 0.282 & 0.271 \\
\hline $\mathrm{C}$ & 0.048 & $0.147^{\mathrm{a}}$ & 0.000 & 0.040 & 0.079 \\
\hline $\mathrm{Mg}$ & 0.200 & 0.286 & $0.443^{\mathrm{a}}$ & 0.084 & 0.033 \\
\hline $\mathrm{Si}$ & 0.095 & 0.021 & $0.258^{\mathrm{a}}$ & 0.045 & 0.157 \\
\hline $\mathrm{P}$ & 0.041 & 0.077 & 0.123 & $0.738^{\mathrm{a}}$ & 0.318 \\
\hline $\mathrm{Ca}$ & 0.038 & 0.136 & 0.167 & $0.269^{\mathrm{a}}$ & 0.108 \\
\hline $\mathrm{O}$ & 0.051 & 0.031 & 0.117 & $0.184^{\mathrm{a}}$ & 0.120 \\
\hline $\mathrm{Mn}$ & 0.065 & 0.312 & 0.240 & 0.205 & $0.530^{\mathrm{a}}$ \\
\hline Eigenvalue & 4.065 & 1.208 & 0.816 & 0.474 & 0.223 \\
\hline Cumulative $\%$ & 59.9 & 77.7 & 89.7 & 96.7 & 100 \\
\hline
\end{tabular}

${ }^{\mathrm{a}}$ Largest absolute correlation between each variable and any discriminant function

explained $77.7 \%$ of the total variance. Eighty percent of the phytoliths were correctly classified a priori. Pooled withingroups correlations (Table 4) between discriminating variables and standardized discriminant functions indicated that aluminium contributed significantly in the first discriminant function. Potassium, sulfur and carbon correlated significantly with the second one. Magnesium and silicon were correlated with the third, phosphorus, calcium and oxygen with the fourth, and manganese with the fifth discriminant function. The LDA (as ANOVA) showed that there were significant differences in $\mathrm{Al}$ and $\mathrm{Mg}$ content among samples (Table 4).

Distribution of samples was plotted using LDA based on the first two discriminant functions (Fig. 4). LDA analysis was able to distinguish between samples of coniferous and deciduous species (Fig. 4).

Summarizing the results of the LDA, the following conclusions can be drawn from the result of discriminant

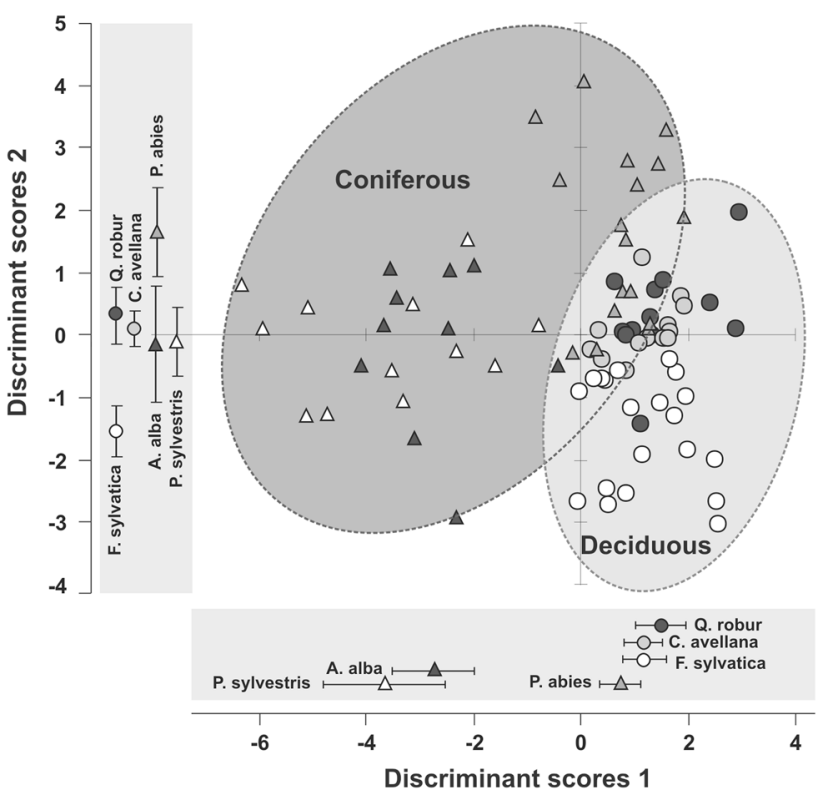

Fig. 4 Discriminant analysis similarity map obtained for the phytolith element content classifications of the studied leaf samples as determined by discriminant factors $1(59.9 \%)$ and $2(17.8 \%)$, plus average discriminant scores and $95 \%$ confidence intervals for species (along the axes)

analysis: The sampled phytoliths of coniferous species were defined by their aluminium concentrations, which were higher than those of the remaining phytolith samples of deciduous species; These assays showed that using 10 elements allows for a useful differentiation of species based on leaf phytoliths.

\section{Discussion}

Biogenic silica content data obtained for the leaves of the six species indicated that deciduous species produced higher biogenic silica content than coniferous species. The highest value of silica was found in $Q$. robur leaves. Based on the accessible literature, this high silica value of $Q$. robur leaves 
is much higher than the silica content in other Quercus species leaves (0.4\% in Q. macrocarpa; Piperno 2006). In this study, the extracted silica content in leaves of $A$. alba is higher than the value reported by Carnelli et al. (2001) (Table 1). Silica percentage values of $P$. abies needles are between 0.3 and $3.7 \%$, and are between 0.05 and $1.2 \%$ in $P$. sylvestris reported by other authors (Bartoli and Souchier 1978; Klein and Geis 1978; Hodson et al. 1997; Carnelli et al. 2001; Cornelis et al. 2010); our results are also between these values. The genus Picea heavily accumulates $\mathrm{Si}$, as other authors already noted (Klein and Geis 1978; Hodson and Sangster 1999), and the high silica content in P. abies needles also has been reported by Carnelli et al. (2001). The silica content of leaves of C. avellana, F. sylvatica and $Q$. robur are described here for the first time. Carnelli et al. (2001) studied the silica content of different families (43 species) from temperate regions and they found an extremely wide range of opal silica content $(0.01 \pm 8.8 \%)$ for arborescent dicotyledons. The opal content in woody Alnus viridis $(0.13 \%)$ and Salix helvetica $(0.04 \%)$ was low (Carnelli et al. 2001). They reported that the herbaceous dicotyledons considered in their study seemed to exclude silicon. However, it is necessary to note that Carnelli et al. (2001) focused on the subalpine region of the Alps. In general, herbaceous dicotyledons have been reported to contain on average less than 1\% silica (Jones and Handreck 1967), significantly less than monocotyledons. Apparently, the methods used to measure silica and the soil conditions of the sampled plant could have been different in the cited literature, which could explain the different silica content results. For instance, silica content in $F$. sylvatica and $Q$. robur leaves were consistently lower in the study of Cornelis et al. (2010) than our values.

With regard to the phytolith assemblages, the ash of $Q$. robur leaves was rich in identifiable phytoliths (eight morphotypes) that matches the high biogenic silica content (bSi) content measured previously. Characteristic epidermal phytoliths of deciduous species were found: strongly silicified jigsaw epidermal cells may be indicative of $C$. avellana and $F$. sylvatica, at the same time isodiametric epidermal cells are a feature of $Q$. robur. Stomata of A. alba and P. sylvestris were more silicified and durable than stomata of $P$. abies needles. Consequently, a phytolith assemblage abundant in conifer-type stomata may be indicative of vegetation dominated rather by $A$. alba or $P$. sylvestris than $P$. abies.

The more or less cubical BLOCKY form of $P$. abies needles was well characterized regarding our results, and we were looking for further possible synonyms or previous findings of this morphotype. Earlier Rovner (1971) referred to polyhedral cells of conifers as "irregular polyhedron" in the case of Picea glauca needles, but he did not report more or less regular cubic forms in this species. Klein and Geis (1978) mentioned "endodermal polyhedrons" of Picea genus, so they make it likely that the possible anatomical origin of these phytoliths were endodermal cells. Strömberg (2004) mentioned "blocky polyhedron" phytoliths, but she observed this type not only in conifers, but also in grasses and dicotyledons. Carnelli et al. (2004) described a similar phytolith type as "block-ridged" and mentioned it as a diagnostic phytolith type of P. abies and Pinus mugo. Bozarth (1993) reported "blocky smooth polyhedrons" in Picea glauca and "blocky polyhedrons with grainy surfaces" in P. mariana needles. These data proved that phytoliths similar to the "Picea-BLOCKY type" phytoliths might have been observed earlier in the genus Picea, but the anatomical origin was not clear in detail and not separated from polyhedrons with other anatomical origins or of other coniferous species. Furthermore, POLYHEDRAL phytoliths of A. alba and P. sylvestris needles were at least three times longer than wide, implying that these cells may have a transport function more likely than that of Picea-BLOCKY type phytoliths.

After examining 15 taxa of Pinaceae, Klein and Geis (1978) concluded that the identification of conifers was possible on the basis of tracheary elements, blocky polyhedrons and epidermal cells. Our study also provides phytolith data with reference values, considering the characteristic epidermal phytoliths of deciduous species and differences were found in silicified transfusion cell forms in conifers.

Determining the anatomical origin of the characteristic phytoliths is important, as in the case for most of the phytolith assemblages of different plant taxa, we have to deal with the case of "multiplicity and redundancy" (Rovner 1971). At the same time, the taxonomical relevance of the BLOCKY and PolyhedRal phytoliths in the leaves of the sampled conifers was remarkable. It was assumed that the BLOCKY and POLYHEDRAL morphotypes of different species may originate from different anatomical positions, and so cross and longitudinal sections were studied to find the specific tissue areas of the silica accumulation. The form of the $\mathrm{Si}$ accumulation of $P$. abies needles described above was not found in the Picea glauca needles (Hodson and Sangster 1998, 1999). As the latter authors reported, the inner tangential wall of the hypodermis is the primary site of silica deposition in the needles of $P$. glauca and there was an increase in silica deposition with time at this location. Hodson and Sangster (1998) found endodermal accumulation of silicon in $P$. glauca, but it was too variable to be confirmed by analysis of variance.

Hodson and Sangster (1999) listed major sites of silica accumulation in the needles of coniferous species. According to their study, the most important deposition is in the cell walls of the epidermis and hypodermis, the outermost tissues of the needle. Another frequent site of deposition is the endodermis, and the third one is in the calcium oxalate crystals of the mesophyllum. As Hodson and Sangster (2002) described, silicon was concentrated in the extreme tips of the Pinus strobus needles in all tissues, but especially in the transfusion tissue. At the same 
time, observation of a well-characterized phytolith layer was not mentioned in their study. Hodson and Sangster (1999) showed conclusive SEM images (their Fig. 5 F, G) of silicified endodermis cells in $P$. glauca needles. In spite of the previous work, our results suggest that the most important location of silica accumulation is the transfusion cells adjacent to the inner side of the endodermis of $P$. abies needles. This implies that there is a remarkable difference in the localization of the silicon accumulation between the P. glauca and P. abies species, within the same genus. Ghimire et al. (2015) also reported on similar result, namely that anatomical characteristics of the Picea needles were useful for species differentiation.

The reason of this difference of the $\mathrm{Si}$ accumulation is not clear. It seems that the stream of fluid with high silicon content is blocked along the way from the xylem to the mesophyll tissue in the transfusion tissue and cannot enter into the endodermis in P. abies needles. The silicon block may be a result of the functional intensity and dynamic or density of the aquaporins in the cell membranes of the endodermis cells (Laur and Hacke 2014; Mayr et al. 2014). As the water flow from the xylem to the mesophyll cells takes place across the transfusion tracheids (Bäck et al. 2013), consequently the Picea-BLOCKY type may originate from the transfusion tracheid cells, especially as bordered pits were observed on the surfaces of a few of them by us and An (2016). On the other hand, the physiological role of the transfusion parenchyma cells is ensuring the sugar flow (Bäck et al. 2013) and storage of different secondary products of the metabolism (Stelzer et al. 1990). The latter authors reported sporadic appearance of $\mathrm{Si}$ in transfusion parenchyma cells, but data were not shown in their paper. Morever, it is an undoubted fact that some of the PiceaBLOCKY type phytoliths are without bordered pits, and this is an anatomical feature of the transfusion parenchyma cells (Huber 1947; Heimerdinger 1951; Liesche et al. 2011). Summarizing, since there is some evidence for a tracheidal origin as well as a parenchymal origin, it seems that PiceaBLOCKY type phytoliths may develop from both of them.

Although the proportion of the different elements in phytoliths is related to the environment of plant habitats and the plant species (Hodson 2016), we can establish some of the distribution of the elements in the phytoliths. As the phytoliths in the leaves of the sampled species originated from different tissues and may be from different anatomical positions, consequently phytoliths with different origins may play different roles in the elemental transport of the leaves and in this case differences in phytolith elemental content may be found among these species. Our samples contained $\mathrm{Si}, \mathrm{O}, \mathrm{C}, \mathrm{Mg}, \mathrm{Al}, \mathrm{P}, \mathrm{S}, \mathrm{K}, \mathrm{Ca}, \mathrm{Mn}, \mathrm{Na}, \mathrm{Ti}, \mathrm{Ba}, \mathrm{Fe}$. Hodson and Sangster (2002) described further elements: $\mathrm{Cl}, \mathrm{Cu}$ and $\mathrm{Zn}$ in Pinus strobus needles, but did not observe Ti and $\mathrm{Ba}$ in their samples. Hart (2001), studying two species, confirmed the presence of $\mathrm{Ti}$ in phytoliths, as well as $\mathrm{Al}, \mathrm{Fe}, \mathrm{Mg}, \mathrm{Ca}$, $\mathrm{Na}, \mathrm{Mn}, \mathrm{K}$, and $\mathrm{C}$.

Silicon was reported to increase with needle age in $P$. glauca by Hodson and Sangster (1998), in P. abies by Wyttenbach et al. (1991) and in P. rubens by Meng et al. (1995). This tendency of silica accumulation was not studied here, however, it may be important to focus on this in the future, along with the question of whether elemental composition could also increase with needle age.

As Hodson established in his review (Hodson 2016), many other carbon values for phytoliths can be found in the literature. However, it is not beneficial to compare data measured using different methods. For example, our carbon data were appreciably different from the value of $0.96 \%$ carbon in phytoliths that was reported by Jones and Beavers from silt loam after acid extraction (Jones and Beavers 1963 in Hodson 2016). Hodson et al. (2008) made a study of different organs in wheat (Triticum aestivum) by the dry ashing method and found that the carbon content varied from 0.07 to $1.72 \%$ depending on the organ. By contrast, Parr et al. (2010), using microwave digestion as a preparative method, observed a higher concentration of carbon in the phytoliths of ten bamboo species, ranging between $1.4 \%$ and $4 \%$, similar to our results. Overall, measured carbon content of phytoliths may depend on the species, on the tissue type of the revealed organ from which the phytolith originated, and may strongly depend on the preparation technique and also the measuring method (Hodson 2016).

There was higher concentration of magnesium in phytoliths of needles than in phytoliths of deciduous species. Stelzer et al. (1990) and Wienhaus et al. (2001) found that magnesium was at low levels throughout the needles of $P$. abies, and they noted that it was concentrated in the endodermis (see also for P. glauca, Hodson and Sangster 1998). We hypothesize that there is a correlation between the higher magnesium concentration of the endodermis (as established in the literature) and the high magnesium content of the needle phytoliths originating from the central cylinder (as we found in P. abies needles).

Aluminium content was also higher in phytoliths of conifers than phytoliths of deciduous species. Carnelli et al. (2002) also found that phytoliths from the conifer species had a higher concentration of aluminium than those from Poaceae and Cyperaceae. Hodson (2016) emphasized that the aluminium content in phytoliths also depends on the availability of aluminium in the soil because this is much greater in acidic soils than in neutral or alkaline soils (Hodson and Sangster 2002). As a result, the authors suggested caution with regards to the aluminium content of phytoliths as a useful tool for palaeoecological studies. However, our coniferous and deciduous samples were from the same soil without any difference in soil $\mathrm{pH}$, additionally it seems that the higher aluminium content of conifers is confirmed by 
other recent studies (Hodson and Sangster 1999; Hodson 2016).

There were some phosphorus and potassium in the phytoliths of our samples. Hodson and Sangster (2002) mapped the phosphorus distribution in Pinus strobus needles among others, and they also found that it was ubiquitously distributed and in low concentrations. Similarly, accumulation of potassium in the endodermis was established by Stelzer et al. (1990) and Wienhaus et al. (2001) in P. abies needles, as well as Hodson and Sangster (1998) in P. glauca needles. The values for calcium were relatively high, and one of the possible reasons for this is that $\mathrm{Ca}$ is an important structural element of the cell walls (Hart 2001; Hodson and Sangster 2002; Fraysse et al. 2009; Buján 2013). Corylus avellana epidermis was rich in calcium-oxalate crystals; accordingly among the studied broad-leaved species the highest $\mathrm{Ca}$ value was measured in its phytoliths; probably some calcium-oxalate remains were present in the silicified idioblasts. Calcium and silicon may be attached to each other in the plant structural system, as has been confirmed in the literature (Hodson and Sangster 1999; Serdar and Demiray 2012). The previous authors reported that silicon is also often found in the calcium oxalate crystals of the mesophyll in the needles. Hodson and Sangster (2002) reported results similar to ours, as manganese was detected in small amounts in epidermis, endodermis and transfusion tissue of Pinus strobus needles, and they found some sulfur in almost every tissue.

The discriminant analysis showed that the elemental content of phytoliths of coniferous and deciduous species differed mainly in the accumulation of aluminium and magnesium. The most obvious reason is that measured phytoliths from deciduous tree leaves were mainly from the epidermal basic cells and stomatal cells, but phytoliths of conifer needles were from the inside of the central cylinder of the needle. These latter silicified cells are active participants in the fluid transport of the plant thus the cell walls of these cells directly incorporate elements from plant fluid that is taken up by the roots from the soil. The results of Hodson and Sangster (2002) confirm this hypothesis, as they reported that $\mathrm{Al}$ and $\mathrm{Mg}$ could be found in the inner part of the central cylinder, in the transfusion tissue and in the endodermis. The difference in some elemental content between species was established in Hart (2001), who detected 24 elements in phytoliths of two species. We note that the elemental content of $P$. abies needle phytoliths is more similar to the deciduous species studied than to the elemental content of the coniferous phytoliths. This confirms that the anatomical origin of the $P$. abies cubical phytoliths is different. As Hodson and Sangster (2002) established, "phytoliths are not homogeneous and consist of at least two main types, lumen and cell wall, which would be expected to have very different chemical and isotopic contents". As Hodson (2016) emphasized, using elemental as well as isotopic markers as proxies in palaeoecology will be reliable only in the event that our knowledge of the development of phytoliths is better understood.

\section{Conclusions}

1. The studied deciduous species contained more silica in their leaves than conifer species did. Since the samples originate from the same environmental conditions, this suggests that deciduous species accumulate more silica in their leaf tissue than the conifer species under similar environmental conditions. Relatively high silica content was found in Quercus robur leaves, and Picea abies leaves had the highest silica content among the studied conifers.

2. We observed characteristic epidermal phytoliths of deciduous species, as well as some differences were found in silicified transfusion cell forms within the conifers. The cubic-like BLOCKY morphotype described from Picea abies needles is a characteristic one for this species. Although the multiplicity and redundancy phenomenon hinders the exact and unambiguous identification of a plant species solely based on their phytoliths, however it is important to stress that comparative phytolith research is essential for finding phytoliths with taxonomic relevance.

3. The anatomical position of the characteristic silicified transfusion cells was identified in Picea abies needles. We found that a specific phytolith layer developing from more or less cubical BLOCKY phytoliths becomes continuous towards the apex of the needle.

4. The silicic acid is probably trapped in the transfusion tracheids and/or stored in the transfusion parenchyma cells close to the endodermis in the Picea abies needles, and this is the origin of the cubical BLOCKY phytoliths. Our hypothesis is that silicic acid is being concentrated in the transfusion tissue near the endodermis at a higher level than in the xylem, and does not enter the endodermis.

5. High concentrations of magnesium and aluminium in phytoliths are indicative of Abies alba and Pinus sylvestris species. Because this result is confirmed by several other authors in connection with other conifer species, this phenomenon may be considered as a useful proxy in future palaeoenvironmental studies, if measured on several phytoliths. It is important to mention that the element content of Picea abies needle phytoliths was more similar to the deciduous species studied than to the element content of the coniferous phytoliths. It will be important to study the $\mathrm{Si}$ accumulation and phytoliths developed in the Picea abies needles of several whole trees in detail. 
6. Finally, the description of the characteristic BLOCKY morphotype: "Picea-BLOCKY type" phytolith layer of Norway spruce needles and significantly more aluminium and magnesium content in the phytoliths of needles gives us the possibility of identifying the taxa based on phytoliths from soils and sediments. Moreover, PiceaBLOCKY type as a phytolith type with the same anatomical origin, position and function-allows comparative, in situ, isotopic studies to provide the possibility of finding further measurable proxies.

\begin{abstract}
Acknowledgements Open access funding provided by MTA Institute for Nuclear Research (MTA ATOMKI). The research was supported by the European Union and the State of Hungary, co-financed by the European Regional Development Fund in the project of GINOP-2.3.2.15-2016-00009 'ICER'. The last author's work was supported by the János Bolyai Research Scholarship of the Hungarian Academy of Sciences; National Research, Development and Innovation Office [Grant number PD_124607]. Moreover, we thank László Papp (Director, Botanical Garden of Debrecen University, Hungary) for his collaboration in sampling. We would like to thank Timothy Jull and Katharina Neumann for their comments on the manuscript.
\end{abstract}

Open Access This article is distributed under the terms of the Creative Commons Attribution 4.0 International License (http://creativeco mmons.org/licenses/by/4.0/), which permits unrestricted use, distribution, and reproduction in any medium, provided you give appropriate credit to the original author(s) and the source, provide a link to the Creative Commons license, and indicate if changes were made.

\section{References}

Aitchison J (1986) The statistical analysis of compositional data. Chapman and Hall, London

Albert RM, Weiner S (2001) Study of phytoliths in prehistoric ash layers from Kebara and Tabun caves using a quantitative approach. In: Meunier JD, Coline F (eds) Phytoliths: applications in earth sciences and human history. Balkema, Lisse, pp 251-266

An X-H (2016) Morphological characteristics of phytoliths from representative conifers in China. Palaeoworld 25:116-127

An X-H, Lu H, Chu G (2015) Surface soil phytoliths as vegetation and altitude indicators: a study from the southern Himalaya. Sci Rep 5:15,523

Bäck J et al (2013) Processes in living structures. In: Hari P, Heliövaara K, Kulmala L (eds) Physical and physiological forest ecology. Springer, Dordrecht, pp 43-223

Bartoli F, Souchier B (1978) Cycle et rôle du silicium d'origine végétale dans les écosystèmes forestiers tempérés. Ann Sci For 35:187-202

Bartoli F, Wilding LP (1980) Dissolution of biogenic opal as a function of its physical and chemical properties. Soil Sci Soc Am J 44:873-878

Birks HH, Birks HJB (2006) Multi-proxy studies in palaeolimnology. Veget Hist Archaeobot 15:235-251

Blinnikov MS (1994) Phytolith analysis and Holocene dynamics of alpine vegetation. In: Onipchenko VG, Blinnikov MS (eds) Experimental investigations of alpine plants communities in the northwest Caucasus. Veröffentlichungen des Geobotanischen Instituts der ETH 115. Stiftung Rübel, Zürich, pp 23-40
Bozarth S (1993) Biosilicate assemblages of boreal forests and aspen parklands. In: Pearsall DM, Piperno DR (eds) Current research in phytoliths analysis: applications in archeology and paleoecology, MASCA Research Papers in Science and Archaeology, vol 10. University of Pennsylvania, Philadelphia, pp 95-105

Bremond L, Alexandre A, Vela E, Guiot J (2004) Advantages and disadvantages of phytolith analysis for the reconstruction of Mediterranean vegetation: an assessment based on modern phytolith, pollen and botanical data (Luberon, France). Rev Palaeobot Palynol 129:213-228

Buján E (2013) Elemental composition of phytoliths in modern plants (Ericaceae). Quat Int 287:114-120

Buró B, Sipos G, Lóki J, Andrási B, Félegyházi E, Négyesi G (2016) Assessing Late Pleistocene and Holocene phases of aeolian activity on the Nyírség alluvial fan, Hungary. Quat Int 425:183-195

Carnelli AL, Madella M, Theurillat JP (2001) Biogenic silica production in selected alpine plant species and plant communities. Ann Bot 87:425-434

Carnelli AL, Madella M, Theurillat JP, Ammann B (2002) Aluminum in the opal silica reticule of phytoliths: a new tool in palaeoecological studies. Am J Bot 89:346-351

Carnelli AL, Theurillat JP, Madella M (2004) Phytolith types and typefrequencies in subalpine-alpine plant species of the European Alps. Rev Palaeobot Palynol 129:39-65

Chen ST, Smith SY, Sheldon ND, Strömberg CAE (2015) Regionalscale variability in the spread of grasslands in the late Miocene. Palaeogeogr Palaeoclimatol Palaeoecol 437:42-52

Cornelis JT, Ranger J, Iserentant A, Delvaux B (2010) Tree species impact the terrestrial cycle of silicon through various uptakes. Biogeochemistry 97:231-245

Epstein E (1999) Silicon. Annu Rev Plant Physiol Plant Mol Biol 50:641-664

Fraysse F, Pokrovsky OS, Schott J, Meunier JD (2009) Surface chemistry and reactivity of plant phytoliths in aqueous solutions. Chem Geol 258:197-206

Ghimire B, Lee C, Yang J, Heo K (2015) Comparative leaf anatomy of some species of Abies and Picea (Pinaceae). Acta Bot Brasilica 29:346-353

Hart DM (2001) Elements occluded within phytoliths. In: Meunier JD, Coline F (eds) Phytoliths: applications in earth sciences and human history. Balkema, Lisse, pp 313-316

Hart TC (2016) Issues and directions in phytolith analysis. J Archaeol Sci 68:24-31

Heimerdinger G (1951) Zur Mikrotopographie der Saftströme im Transfusionsgewebe der Koniferennadel II: Mitteilung. Entwicklungsgeschichte und Physiologie. Planta 40:93-111

Hodson MJ (2016) The development of phytoliths in plants and its influence on their chemistry and isotopic composition. Implications for palaeoecology and archaeology. J Archaeol Sci 68:62-69

Hodson MJ, Sangster AG (1998) Mineral deposition in the needles of White Spruce [Picea glauca (Moench.) Voss]. Ann Bot 82:375-385

Hodson MJ, Sangster AG (1999) Aluminium/silicon interactions in conifers. J Inorg Biochem 76:89-98

Hodson MJ, Sangster AG (2002) X-ray microanalytical studies of mineral localisation in the needles of white pine (Pinus strobus L.). Ann Bot 89:367-374

Hodson MJ, Sangster AG, Parry DW (1985) An ultrastructural study on the developmental phases and silification of the glumes of Phalaris canariensis L. Ann Bot 55:649-665

Hodson MJ, Williams SE, Sangster AG (1997) Silica deposition in the needles of the Gymnosperms I: Chemical analysis and light microscopy. In: Pinilla A, Juan-Tresserras J, Machada MJ (eds) The state-of-the-art of phytoliths in soil and plants. Monografias del Ciencias Medioambientales 4. Consejo Superior de Investigacion Científicas, Madrid, pp 123-133 
Hodson MJ, Parker AG, Leng MJ, Sloane HJ (2008) Silicon, oxygen and carbon isotope composition of wheat (Triticum aestivum L.) phytoliths: implications for palaeoecology and archaeology. J Quat Sci 23:331-339

Hubay K, Braun M, Buczkó K et al (2018) Holocene environmental changes as recorded in the geochemistry of glacial lake sediments from Retezat Mountains, South Carpathians. Quat Int 477:19-39

Huber B (1947) Zur Mikrotopographie der Saftströme im Transfusionsgewebe der Koniferennadel I: Mitteilung. Anatomischer Teil Planta 35:331-351

International Committee for Phytolith Taxonomy (ICPT) Neumann K, Albert RM, Ball T, Cummings LS, Strömberg C, Vrydaghs L (2019) International code for phytolith nomenclature (ICPN) 2.0. Annals of Botany (under review)

Jones LHP, Handreck KA (1967) Silica in soils plants and animals. Adv Agron 19:107-149

Juhász I (2005) An overview of the palaeobotanical data from KelemérKis-Mohos-tó. In: Gál E, Juhász I, Sümegi P (eds) Environmental Archaeology in North-Eastern Hungary. Varia Archaeologica Hungarica 19. Archaeological Institute of the Hungarian Academy of Sciences, Budapest, pp 47-54

Kiseleva NK (1992) Botanicheskij I fitolitnyj analiz golotsenovyh otlozhenij of mammal dung in North Ossetiya (in Russian). In: Onipchenko V, Pavlova I, Dinesman L et al (eds) Istoricheskaya ekologiya dikih i domashnih kopytnyh. Istorya pastbischnyh ekosistem. Nauka, Moscow, pp 24-83

Klein RL, Geis J (1978) Biogenic silica in the Pinaceae. Soil Sci 126:145-156

Laur J, Hacke UG (2014) Exploring Picea glauca aquaporins in the context of needle water uptake and xylem refilling. New Phytol 203:388-400

Lentfer CJ, Boyd WE (1998) A comparison of three methods for the extraction of phytoliths from sediments. J Archaeol Sci $25: 1,159-1,183$

Liesche J, Martens HJ, Schulz A (2011) Symplasmic transport and phloem loading in gymnosperm leaves. Protoplasma 248:181-190

Magyari EK, Kunes P, Jakab G et al (2014) Late Pleniglacial vegetation in eastern-central Europe: are there modern analogues in Siberia? Quat Sci Rev 95:60-79

Mayr S, Schmid P, Laur L, Rosner S, Charra-Vaskou K, Dämon B, Hacke UG (2014) Uptake of water via branches helps timberline conifers refill embolized xylem in late winter. Plant Physiol $164: 1,731-1,740$

Meng FR, Bourque CP, Belczewski RF, Whitney NJ, Arp PA (1995) Foliage responses of spruce trees to long-term low-grade sulfur dioxide deposition. Environ Pollut 90:143-152

Mercader J, Astudillo F, Barkworth M et al (2010) Poaceae phytoliths from Niassa Rift, Mozambique. J Archaeol Sci 37:1,953-1,967

Molnár A, Végvári Z (2017) Reconstruction of early Holocene Thermal Maximum temperatures using present vertical distribution of conifers in the Pannon region (SE Central Europe). Holocene 27:236-245

Mulholland SC, Lawlor EJ, Rovner I (1992) Annotated bibliography of phytolith systematics. In: Rapp G Jr, Mulholland SC (eds) Phytolith systematics: emerging issues. Plenum Press, New York, pp 277-322

Neumann K, Chevalier A, Vrydaghs L (2017) Phytoliths in archaeology: recent advances. Veget Hist Archaeobot 26:1-3

Norušis MJ (1990) SPSS/PC + Advanced Statistics 4.0 for the IBM $\mathrm{PC} / \mathrm{XT} / \mathrm{AT}$ and PS/2. SPSS Inc, Chicago

Osterreith M, Madella M, Zurro D, Alvarez MF (2009) Taphonomical aspects of silica phytoliths in the loess sediments of the Argentinean Pampas. Quat Int 193:70-79

Parr J, Sullivan L, Chen B, Ye G, Zheng W (2010) Carbon bio-sequestration within the phytoliths of economic bamboo species. Glob Chang Biol 16:2,661-2,667
Piperno DR (1988) Phytolith analysis: an archeological and geological perspective. Academic Press, London

Piperno DR (2006) Phytoliths: a comprehensive guide for archaeologists and paleoecologists. AltaMira Press, Lanham

Rosen A (1994) Identifying ancient irrigation: A new method using opaline phytoliths from Emmer wheat. J Archaeol Sci 21:125-132

Rovner I (1971) Potential of opal phytoliths for use in palaeoecological reconstruction. Quat Res 1:343-359

Rovner I (1988) Micro- and macro-environmental reconstruction using plant opal phytolith data from archaeological sediments. Geoarchaeology 3:155-165

Sakai T, Zaree G, Sawada Y, Ataabadi MM, Fortelius M (2016) Depositional environment reconstruction of the Maragheh Formation, East Azarbaijan, Northwestern Iran. Palaeobiodivers Palaeoenviron 96:383-398

Serdar B, Demiray H (2012) Calcium oxalate crystal types in three oak species (Quercus L.) in Turkey. Turk J Biol 36:386-393

Smol JP (2002) Pollution of lakes and rivers: a paleoenvironmental perspective. Arnold, London

Solis-Castillo B, Golyeva A, Sedov S, Solleiro-Rebolledo E, LópezRivera S (2015) Phytoliths, stable carbon isotopes and micromorphology of a buried alluvial soil in Southern Mexico: a polychronous record of environmental change during Middle Holocene. Quat Int 365:150-158

Soó R (1930) Összehasonlító erdei vegetációtanumányok az Alpokban, a Kárpátokban és a Magyar Középhegységben. Erdészeti Kísérletek 32:439-475

Soukup M, Martinka M, Cigáň M, Ravaszová F, Lux A (2014) New method for visualization of silica phytoliths in Sorghum bicolor roots by fluorescence microscopy revealed silicate concentrationdependent phytolith formation. Planta 240:1,365-1,372

Soukup M, Martinka M, Bosnić D, Ćaplovićová ER, Lux A (2017) Formation of silica aggregates in sorghum root endodermis is predetermined by cell wall architecture and development. Ann Bot 120:739-753

Stelzer R, Lehmann H, Kramer D, Lüttge U (1990) X-ray microprobe analyses of vacuoles of spruce needle mesophyll, endodermis and transfusion parenchyma cells at different seasons of the year. Bot Acta 103:415-423

Strömberg CAE (2004) Using phytolith assemblages to reconstruct the origin and spread of grass-dominated habitats in the great plains of North America during the late Eocene to early Miocene. Palaeogeogr Palaeoclimatol Palaeoecol 207:239-275

Swan ARH, Sandilands M (1995) Introduction to geological data analysis. Blackwell Scientific Publications, Oxford

Tapody RO, Gulyás S, Törôcsik T, Sümegi P, Molnár D, Sümegi BP, Molnár M (2018) Radiocarbon-dated peat development: anthropogenic and climatic signals in a Holocene raised bog and lake profile from the Eastern part of the Carpathian Basin. Radiocarbon $60: 1,215-1,226$

Wienhaus O, Zimmermann F, Bäucker E (2001) Localisation of manganese, sulphur, potassium and magnesium in needle tissues of spruce (Picea abies (L.) KARST.) in eastern parts of Erzgebirge Mountains on sites with different manganese and magnesium supply. Phyton 41:179-202

Woodburn TL, Johnson WC, Mason JA, Bozart SR, Halfen AF (2017) Vegetation dynamics during the Pleistocene-Holocene transition in the central Great Plains. USA Holocene 27:155-163

Wyttenbach A, Tobler L, Bajo S (1991) Silicon concentration in spruce needles. J Plant Nutr Soil Sci 154:253-258

Publisher's Note Springer Nature remains neutral with regard to jurisdictional claims in published maps and institutional affiliations. 